\title{
Rheumatoid arthritis, juvenile arthritis, iridocyclitis and the Epstein-Barr virus
}

\author{
A J GEAR, ${ }^{14}{ }^{4} \mathrm{~J}$ W VENABLES, ${ }^{2} \mathrm{~J}$ M B EDWARDS, ${ }^{3} \mathrm{R} \mathrm{N}$ MAINI, ${ }^{2}$ \\ AND B M ANSELL \\ From the ${ }^{1}$ Clinical Research Centre, Northwick Park Hospital, Harrow, London; ${ }^{2}$ the Clinical Immunology \\ Division, Kennedy Institute of Rheumatology; the ${ }^{3}$ Virus Reference Laboratory, Central Public Health \\ Laboratory, and the ${ }^{4}$ Rheumatology Unit, University of the Witwatersrand Johannesburg
}

SUMMARY In order to examine the relation of Epstein-Barry virus (EBV) infection to chronic arthritis in children antibodies to EB virus capsid antigen (EBVCA) and rheumatoid arthritis nuclear antigen (RANA) were analysed in sera from 133 patients classified as juvenile rheumatoid arthritis (JRA) or pauciarticular, polyarticular, or systemic juvenile chronic arthritis. Except for an increased frequency in the systemic subgroup, the prevalence of antibodies to EBVCA and titres of anti-RANA antibodies was similar in patients and controls. These data do not support an aetiological role for EBV in chronic arthritis in children, including JRA, and suggest that the mechanisms which may account for the higher titres of anti-RANA antibodies in adult RA do not occur in children.

Key phrase: antibodies to rheumatoid arthritis nuclear antigen.

The possibility of an association between rheumatoid arthritis (RA) and the Epstein-Barr virus (EBV) excites interest for two reasons: firstly, as identifying a possible aetiological agent and secondly, because of evidence of an abnormal responsiveness to the virus. It is now clear that EBV cannot be the sole aetiological agent, since several studies ${ }^{1-}$ ${ }^{3}$ have reported RA patients without antibodies to EB viral capsid antigens (VCAs) which are regarded as a reliable marker of previous EBV infection. Evidence for an abnormal response to the virus is often stated to be the finding of higher titres of antibodies to EBVCA, EB nuclear antigen (EBNA), and early antigen (EA) in sera from RA patients, though these studies disagree on the specificity of the antibodies that are raised. Although these studies are controversial, ${ }^{14-7}$ there is general agreement that RA patients have higher titres of antibodies to rheumatoid arthritis nuclear antigen (RANA), originally described as a soluble cellular protein induced by EBV. This relation to the virus is supported by a close correlation between

Accepted for publication 17 May 1985.

Correspondence to Dr P J W Venables, Division of Clinical Immunology, Kennedy Institute of Rheumatology, 6 Bute Gardens, London W6 7DW.
anti-EBVCA and anti-RANA in normal sera, ${ }^{8}$ but $\stackrel{2}{\Rightarrow}$ its significance in RA is questioned by the finding of $\frac{3}{3}$ anti-RANA in some RA sera that do not contain antibodies to EBVCA. ${ }^{7}$ However, the use of such seroepidemiological methods in adult disease is complicated by the fact that over $90 \%$ of normalo individuals in urban areas have serological evidence of previous EBV infection by the age of $20 .^{9}$

An approach is to examine children in whom the frequency of EBV infection is much lower. ${ }^{9}$ One $₹$ study failed to show an increased prevalence of anti-VCA in juvenile chronic arthritis (JCA), ${ }^{10}$ but $>$ in this survey there was no analysis based on the classification into its subgroups: pauciarticular, $\bar{N}$ polyarticular, systemic, and rheumatoid factor posi-tive juvenile rheumatoid arthritis (JRA). ${ }^{11}$ Since ${ }^{N}$ these may be different diseases with different $\mathrm{N}$ aetiologies, ${ }^{12}$ it is possible that this survey may have missed a higher frequency of anti-VCA in thoseo resembling adult RA (the JRA groups).

In this study we have compared the frequency of: antibodies to EBVCA in 133 patients with JCA with that expected for this age group. The population was subdivided to see if there was an increased preva- $\stackrel{\mathbb{Q}}{\mathbb{Q}}$ lence of EBV infection in any of the four subgroups,$\stackrel{\mathbb{Q}}{\Omega}$ in particular those with JRA. Antibodies to RANAO were also measured in 53 of these patients plus an 
further 20 to see if the prevalence and titre were comparable with those seen in adult RA or merely reflected the low frequency of EBV infection in childhood.

\section{Patients and methods}

Sera were collected from 133 patients with JCA and divided into subgroups by criteria previously described. $^{11}$ Their ages and classification are summarised in Table 1.

The 14 patients with rheumatoid factor positive JCA (JRA) fulfilled the American Rheumatism Association criteria for the diagnosis of classical or definite RA and were all aged between 10 and 16 . IgG antibodies to VCA were detected by indirect immunofluorescence at a screening dilution of $1: 8 .^{13}$

Anti-RANA antibodies were examined in 73 patients and 20 young controls by immunodiffusion against a soluble extract of Wil 2 cells as previously described. ${ }^{7}$ The antigen source was from the same batch as that reported in the previous study, and analysed results are compared with these findings. All sera were tested blind after only one freeze thawing, without knowledge of diagnosis or VCA antibody status.

\section{STATISTICS}

The prevalence of antibodies in each of the groups was compared with each other and with a similar historical control group described in a previous study. ${ }^{9}$ Significance was determined by the $\chi^{2}$ test.

Table 1 JCA patients studied

\begin{tabular}{lccc}
\hline Subgroup & No & $\begin{array}{l}\text { Age range } \\
\text { (years) }\end{array}$ & $\begin{array}{l}\text { Mean age } \\
\text { (years) }\end{array}$ \\
\hline Pauciarticular & 42 & $2-12$ & $6 \cdot 3$ \\
Polyarticular & 25 & $2-14$ & $9 \cdot 6$ \\
Systemic & 52 & $2-16$ & $9 \cdot 7$ \\
Juvenile RA & 14 & $10-16$ & 13 \\
\hline
\end{tabular}

\section{Results and discussion}

The prevalence of antibodies to VCA in the whole population was $43 \cdot 1 \%$. The relation of antibodies to EBVCA to age and diagnostic subgroups is seen in Table 2. The percentage of children with this marker of previous EBV infection was less than $50 \%$ in all groups with three exceptions. The $64 \%$ in the whole JRA group and the $64 \%$ in the $10-16$-year-old polyarticular group can be accounted for by age, since these percentages are similar to those of normal children of the same age. ${ }^{9}$ The $65 \%$ prevalence in the 5-10-year-old systemic group is higher than expected.

The $52 \%$ in the whole systemic group is significantly increased ( $p>0.05)$ compared with the pauciand polyarticular groups combined. This can be accounted for by the high prevalence in the under 10 year olds which could be due to the increased exposure of these young children to the EB virus during their relatively frequent hospital admissions, a phenomenon previously described by Pereira $e t$ al. ${ }^{14}$ On the other hand, it is conceivable that EBV could be an initiating agent in some patients with systemic JCA, though the normal frequency in the older patients would argue against this. In addition if the historical control group 9 is used for comparison the prevalence is not significantly increased, though the pauciarticular group has a significantly decreased frequency. The low prevalence of antiVCA antibodies in pauci- and polyarticular JCA again reflects their age and is strong evidence against EBV being of any significance in these subgroups. A similar conclusion can be drawn for the iridocyclitis in JCA, as four patients with this complication had no serological evidence of previous $E B V$ infection.

Anti-RANA antibodies were detected in 17 out of 73 patients with JCA (23\%) and six out of 20 controls $(30 \%)$ (Table 3$)$. Twenty nine patients were VCA positive and of these $15(52 \%)$ had antiRANA antibodies, similar to the findings for the adult controls where, among VCA positive sera, $63 \%$ were anti-RANA positive. The titres were also

Table 2 Prevalence of antibodies to EBVCA in JCA

\begin{tabular}{|c|c|c|c|c|c|c|c|c|}
\hline \multirow{2}{*}{$\begin{array}{l}\text { Age } \\
\text { (years) }\end{array}$} & \multicolumn{2}{|l|}{ Pauci } & \multicolumn{2}{|l|}{ Poly } & \multicolumn{2}{|l|}{ Systemic } & \multicolumn{2}{|l|}{$J R A$} \\
\hline & $V C A+/ N o$ & $\%$ & $V C A+/ N o$ & $\%$ & $V C A+/ N o$ & $\%$ & $V C A+/ N o$ & $\%$ \\
\hline $0-5$ & $2 / 20$ & 10 & $0 / 3$ & 0 & $5 / 11$ & 45 & $0 / 0$ & 0 \\
\hline $5-10$ & $7 / 17$ & 41 & $2 / 11$ & 18 & $13 / 20$ & 65 & $0 / 0$ & 0 \\
\hline $10-16$ & $2 / 5$ & 40 & $7 / 11$ & 64 & $9 / 21$ & 43 & $9 / 14$ & 64 \\
\hline Total & $11 / 42$ & 26 & $9 / 25$ & 36 & $27 / 52$ & 52 & $9 / 14$ & 64 \\
\hline
\end{tabular}


Table 3 Relationship of antibodies to EBVCA with anti-RANA titres

\begin{tabular}{|c|c|c|c|c|c|c|}
\hline \multirow{3}{*}{$\begin{array}{l}\text { Anti-RANA } \\
\text { titre }\end{array}$} & \multirow{2}{*}{\multicolumn{2}{|c|}{$J C A \quad(n=73)$}} & \multicolumn{4}{|c|}{ Controls } \\
\hline & & & \multicolumn{2}{|c|}{ Children $(n=20)$} & \multicolumn{2}{|c|}{ Adults $(n=93)$} \\
\hline & $V C A+$ & $+V C A-$ & $V C A+$ & $V C A-$ & $V C A+$ & $V C A-$ \\
\hline Neg & 14 & 42 & 6 & 8 & 27 & 17 \\
\hline Neat & 9 & 2 & 2 & 0 & 16 & 3 \\
\hline $1 / 4$ & 4 & 0 & 3 & 0 & 28 & 0 \\
\hline $1 / 16$ & 2 & 0 & 1 & 0 & 2 & 0 \\
\hline Total & 29 & 44 & 12 & 8 & 73 & 20 \\
\hline
\end{tabular}

very similar, the majority being $1 / 4$ or less in both disease and control groups. Thus the titre of anti-RANA and its relation to EBV infection is the same in JCA as it is in normal controls, and the lower overall frequency of anti-RANA merely reflects the lower frequency of EBV infection in children. This is in contrast with adult RA, where not only are the antibodies more frequent $(86 \%)$ but they are also present in higher titres. ${ }^{7}$ No difference could be shown in the titres of anti-RANA between the subgroups, though the numbers became small with subclassification. Out of eight JRA sera tested only two (both from VCA positive individuals) contained anti-RANA, at titres of neat and $1 / 4$. The frequency of anti-RANA antibodies amongst those with systemic JCA was the highest: seven out of 15 $(47 \%)$, probably reflecting the relatively high frequency of anti-EBVCA antibodies in this group.

This study has shown that the frequency of anti-VCA closely correlates with age in JRA, and the lack of a significant increase in frequency in juvenile rheumatoid arthritis provides further evidence against an aetiological role for the virus in RA. The suprising finding of normal levels of anti-RANA antibodies, which were closely related to EBV infection in these children, suggests that the relatively high levels found in adult RA are due to disease mechanisms not found in children and which remain unknown.
We are grateful for the support of the Arthritis and Rheumatisme Council of Great Britain. Dr Gear was supported by an ICI (Ltd) scholarship.

\section{References}

1 Ferrell P B, Aitcheson C T, Pearson G R, Tan E M. Seroepidemiological study of relationships between Epstein- $\varrho$ Barr virus and rheumatoid arthritis. J Clin Invest 1981; 67: ڤ) 681-7.

$2 \mathrm{Ng} \mathrm{K} \mathrm{C.} \mathrm{Perry} \mathrm{J} \mathrm{D,} \mathrm{Brown} \mathrm{K} \mathrm{A,} \mathrm{Holborow} \mathrm{E} \mathrm{J.} \mathrm{Anti} \mathrm{RANA} \vec{\circ}$ antibody: a marker for seronegative and seropositive rheumatoid arthritis. Lancet 1980; i: 447-9.

3 Depper J M, Zvaifler N J. Epstein-Barr virus: its relationship to the pathogenesis of rheumatoid arthritis. Arthritis Rheum 1981; $\overline{\mathrm{D}}$ 24: 755-61.

4 Alspaugh M A. Tan E M. Serum antibody in rheumatoid $\stackrel{G}{ }$ arthritis reactive with a cell-associated antigen: demonstration by precipitation and immunofluorescence. Arthritis Rheum 0 1976: 19: 711-9.

5 Alspaugh M A. Henle G, Lennette E, Henle W. Elevated levels of antibodies to Epstein-Barr virus antigens in sera and synovial fluids of patients with rheumatoid arthritis. $J$ Clin Invest 1981; 67: 1134-40.

6 Silverman S L. Schumacher H R. Antibodies to Epstein-Barr viral antigens in early rheumatoid arthritis. Arthritis Rheum 1981: 24: $1465-8$.

7 Venables P J W, Roffe L M. Erhardt C C, Maini R N. Edwards $\mathrm{J}$ M B. Porter A D. Titers of antibodies to RANA in rheumatoid arthritis and normal sera. Arthritis Rheum 1981; 24: 1459-64.

8 Catalano M. Carson D A, Slovin S F, Richman D D, Vaughan $\mathrm{J} \mathrm{H}$. Antibodies to Epstein-Barr virus determined antigens in normal subjects and in patients with seropositive rheumatoid arthritis. Proc Natl Acad Sci USA 1979; 76: 5825-8.

9 Edwards J M B. Woodroof M. EB virus-specific IgA in serum of patients with infectious mononucleosis and of healthy people of different ages. J Clin Pathol 1979: 32: 1036-40.

10 Phillips P E. Lin W M. Parkman P D. Hashaut Y. Virus antibody and IgG levels in juvenile rheumatoid arthritis [Abstract]. Arthritis Rheum 1973; 16: 126.

11 Ansell B M. Heberden Oration. 1977: Chronic arthritis in childhood. Ann Rheum Dis 1978; 37: 107-20.

12 Clements L E. Albert E. Ansell B M. HLA studies in IgM rheumatoid-factor-positive arthritis of childhood. Ann Rheum Dis 1983: 42: 431-4.

13 Sumaya C V. Henle W. Henle G. Smith M H D. LeBlanc D. Seroepidemiologic study of Epstein-Barr virus infection in a rural community. $J$ Infect Dis 1975; 131: 403-8.

14 Percira M S. Blake J M. Macrac A D. Epstein-Barr virus antibody at different ages. Br Med J 1969; iv: 526-7. 